\title{
CROSS-CULTURAL ADJUSTMENT EXPERIENCES OF ACADEMIC EXPATRIATES IN SOME SOUTH AFRICAN UNIVERSITIES: THE CASE OF KWAZULU-NATAL
}

\author{
T. Ngonyama-Ndou \\ Department of People Management and Development \\ Tshwane University of Technology, eMalahleni Campus \\ Witbank, South Africa \\ e-mail: ngonyama-ndout|@tut.ac.za / https://orcid.org/0000-0001-6669-8155
}

\section{ABSTRACT}

This article discusses the cross-cultural adjustment experiences of selected academic expatriates from selected South African universities based in the KwaZulu-Natal Province. Quantitative data was collected from 142 out of 277 academic expatriates. Statistical procedures were used to analyse, interpret and make meaning of the raw data. The findings revealed that academic expatriates experience general and interaction adjustment challenges associated with the use of local languages and the understanding of local culture. However, female academic expatriates were found to be better adjusted in interaction and general adjustment as compared to their male counterparts. Furthermore, work adjustment challenges triggered by the poor coordination of work permit application were also discovered. The study stressed revision of human resources practices, immigration policies as well as cross-cultural adjustment support for academic expatriates into South African host academic institutions.

Keywords: academic expatriates, higher education institutions, interaction adjustment, general adjustment, work adjustment

\section{INTRODUCTION}

Over the years the South African higher education sector has experienced an increased need to rely on expatriate academics to boost their human resources and expand the pool of much needed skills. Universities are, much like other sectors in South Africa, increasingly joining the global market by jostling for expatriate skills and human resources through the use of the advertising media (Selmer and Lauring 2013). The academic expatriates bring a wealth of skills and expertise that South Africa and its fast-growing industry and economy are in much need of. Faculties in the sciences, engineering and some parts of the management fields have been observed to demand essential skills that usually come with academic migrants and professional expatriates (Maharaj 2011). Supporting the need to recruit academic expatriates, Wocke and Klein (2002) insist that the process of doing so should be carefully and systematically conducted after a scientific audit that establishes exactly which particular skills are in scarcity. 
Such strategic positions in the South African academy such as Vice-Chancellors, Heads of Schools, Heads of Departments and Deans of Faculties that were frequently occupied by privileged white academics are increasingly being occupied by black expatriates that have some of the skill that black South Africans are yet to amass (Ojong 2012) because of the discrimination and disadvantaging that the long history of apartheid put them through. One of the largest institutions of higher learning in the KwaZulu-Natal province is reported to be a major recipient of skilled expatriate academics (Maharaj 2011). Even as academic expatriates have become central in the South African higher education sector, there are few studies and limited literature that has focussed on their experiences (Selmer and Lauring 2013) and how South Africa can better work with them.

Research on expatriates, their experiences and the South African policy frameworks on them is still limited (Maharaj 2011) resulting in limited understanding of the subject of international labour and probably inadequate or inefficient policies related to their work and stay in the country. Maharaj further notes that, academic expatriates in particular, are ignored in studies compared to expatriates in other sectors. Yet scholars in the area of higher education sector note that universities present a different organisational environment with unique work tasks and characteristics that are different from the corporate sector for instance (Selmer and Lauring 2013).

For that reason, the adaptation and cross-cultural adjustment of expatriates in South African higher education might be requiring close examination compared to that of other sectors. This study is an attempt to contribute to the filling of that gap in studies and literature. Towards that, the question of how academic expatriates deal with the psychological, emotional and physical adjustments into South African culture which is complicated by the challenge of xenophobia and xenophobic violence remains a concern. Given the foregoing context, the aim of this study is to examine the cross-culture adjustment challenges faced by academic expatriates in South African higher education.

\section{CONCEPTUAL FRAMEWORK}

This study draws from the U-curve adaptation model (cross-cultural adjustment model). This implies that academic expatriates go through a defined learning process in successfully integrate and adjust to the new work environment. In achieving this, they navigate through four crosscultural adjustment stages, that is, honeymoon, cultural shock, adjustment and mastery. Furthermore, although academic expatriates are expected to adjust at all levels of their lives such as; in the community where they live, at home and at work, the most crucial environment they should adjust to, is work environment where their maximum productivity is expected. 
The U-Curve cross cultural adjustment model, conceptualised by Lysgaard (1955), outlines four stages of cross-cultural adjustment; honeymoon or euphoria, cultural shock, adjustment and mastery. This model suggests that an individual goes through each stage sequentially. The honeymoon or euphoria stage entails excitement about the new encounters in a new a new environment. After this comes cultural shock whereby one gets surprised by the cultural practices within the new environment. The next stage is an adjustment stage which entails an understanding of the culture leading to the final stage, the mastery stage. At mastery stage an individual masters and gets acquainted as well as comfortable with the cultural practices of the new environment which leads to an adjusted individual.

Even though high possibilities for individuals to go through a U-curve pattern of adjustment exist, one should understand that people are unique and may experience adjustment differently (Black and Mendenhall 1991). This means that due to individual differences the amplitude of the different stages maybe vary and may occur at different points in time. For this reason, in some cases the adjustment may take a different form other than a U-shape. Takeuchi and Chen (2013) observed that adjustment may also be influenced by prior international experience of the expatriate academic. Therefore, individuals with prior international experience may experience the cross-cultural model differently. Further, Fomunyam (2012) points out that, amongst other elements, adjustment is influenced by proficiency in local language and culture.

\section{ADJUSTMENT OF ACADEMIC EXPATRIATES}

Adjustment in its various phases and facets is a vital aspect of any change of environment especially in a foreign country and such a strategic sector as the higher education sector. When one changes an environment, a change in living conditions, life style and daily routine, including friends and colleagues, may be expected. This involves moving away from normal routines (comfort zone) to establishing new routines, learning a new organisational culture, a local language, local culture and so forth. Consequently, one has to adapt and adjust in order to fit into the new conditions. For that reason, Fomunyam (2012) observes that migrants should be prepared to change their thinking, attitudes, speech, social conduct and they should look into how they negotiate their stay, who they identify and associate with, and what strategies they use to integrate themselves into South African society. Not only migrants, but this study can add that even host countries and host institutions should develop mechanisms to receive and settle expatriates for mutual benefits.

In essence, adjustment has been described by some scholars as categories in many different types and levels. However, the cross-cultural adjustment conceptualised by Black and 
Mendenhall (1991) studied job factors, organisational factors, positional factors, non-work factors and individual factors. This model distinguished three main dimensions of expatriate adjustment; general adjustment (comfort associated with various non-work factors such as family and life demands), interaction adjustment (comfort associated with interaction with host country nationals such as being able to converse and socialise with colleagues) and work adjustment (comfort associated with the job assignment such as being able to cope with the qualitative and quantitative workload). Therefore, cross-cultural adjustment refers to the level of comfort a professional sojourner experiences during the stay abroad (Black and Mendenhall 1991). Hence, the highlighted dimensions of adjustment are important and integrated as they collectively determine the failure or success of an expatriate's settlement in a new working environment.

\section{CULTURAL ADJUSTMENT}

If expatriates are to be helpful to their host countries and institutions and if host countries and institutions are to be responsive to their needs, cross-cultural adjustment and the processes that go with it should not be ignored. Providing international staff with intercultural competence which leads to effective and appropriate behaviours in the host country is an important, challenging but necessary task in organisations (Graf and Mertesacker 2009). These authors further indicate that the multicultural construct of international competence consists of knowledge about the foreign culture, intercultural sensitivity and effective intercultural behavior. When people move across cultures clashes in values, principles, customs and traditions should be expected.

Moreover, they have certain sets of expectations about what the new culture may be compared to their own culture. In this sense, the bigger the cultural clashes or the gap between the two cultures, the longer it takes for one to adjust to the host culture, and the bigger the cultural shock. Furthermore, Vrosmans and Van Engen (2013), drawing from the unmet expectations theory, indicate that when cultural differences and adjustment problems are undermined the results will be unmet expectations which impact negatively on adjustment. Žižek (2017) notes that migrants from refugees, exiles and expatriates are people who possess certain dreams and hopes that can in turn be fulfilled or upset in the host country, when they are upset, they turn into traumatic nightmares and personal crises. Nyamnjoh (2006) notes that migration necessarily produces insiders and outsiders in the host country, where international citizens and locals encounter each other and that relationship needs to be carefully managed or else it results in tensions and even psychological and physical violence. If not handled expertly, migration and settlement can be traumatic. 


\section{LANGUAGE PROFICIENCY}

In the view of Fanon (1967) language is a carrier of civilisation and a bearer of the weight of the identity of people. Understanding and not understanding a foreign and a local language may create a clash between local and international citizens and may cause traumatic encounters, and cultural tensions. Theoretically, language plays a major role in connecting people from different cultural backgrounds. Through the use of language people express themselves and convey messages; hence, it is critical for newcomers in the community to understand local languages. Not being understood or taken seriously when you communicate is one major frustration in a new culture (Selmer and Lauring 2013).

Therefore, these authors suggest that a newcomer should learn and practice effective communication according to the language and rules of the new setting. Language proficiency facilitates the adjustment process of expatriates in two ways; 1) it enables them to communicate effectively with the locals and it boasts their confidence thereby bridging the language barrier and 2) through demonstration of the ability to communicate and interact with the locals they receive acceptance and support from the locals while they observe, learn and practice local culture and acceptable behaviour.

An observation by Huff (2013) found a strong association between language proficiency and interaction adjustment as well as general adjustment. Huff further reported a negative relationship between language proficiency and work adjustment. This is because in various instances, the local language is different from a business language. In this sense, local language could be the dominant language used to interact amongst locals; however, it may not be the one used for business communication purposes. Even if this is the case, academic expatriates should still learn at least to a basic level the local language to enable them to interact and socialise with locals. This is more so because of their community engagement obligation whereby they should serve and interact with surrounding communities who may not have command of the business language used in a particular organisation but they can only interact in their local language.

Therefore, in the higher education space understanding of local languages is critical not only for interaction and general adjustment but for work adjustment as well. Additionally, Ren et al. (2014) affirm that host country language fluency enables expatriates to communicate and obtain information about the host culture which in turn facilitates their adjustment. Clearly, the subject of language and language proficiency makes demands on both the host and the expatriate to locate a mutually intelligible medium of communication that may not be alienating to both and still professionally productive. There is need for learning and adjustment from all parties involved for the successful migration and settlement to take place. 


\section{OBJECTIVES OF THE STUDY}

The study aimed to achieve the following objectives:

1) To identify work adjustment challenges facing academic expatriates in adjusting to South African higher education work environment.

2) To establish if demographic variables have any impact on the adjustment of academic expatriates to South African higher education work environment.

\section{METHODOLOGY}

The study targeted 277 academic expatriates employed by the selected KZN higher education institutions. Purposive sampling was employed in selecting and sampling those academic expatriates because of their experiences were in a position to supply direct and enriching responses to the objectives and questions of the study. A 5-point Likert Scale questionnaire originally established by Black (1988) was used in the study. The questionnaire has since been adopted, adapted and used in various studies relating to the adjustment of expatriates which reported alpha of 0.78 on general adjustment, alpha of .88 on interaction adjustment and alpha of 0.68 on work adjustment and an overall alpha of 0.74 was reported (Okpara 2010). So, arguably, the questionnaire has been developed and polished as a research instrument. The researcher further developed and piloted the questionnaire. After piloting, the reliability and validity tests performed on the final questionnaire reflected Cronbach's alpha of 0.75 for general adjustment, 0.85 for interaction adjustment and 0.87 for work adjustment. An overall Cronbach's alpha of 0.78 was reflected for the entire questionnaire.

The questionnaire was distributed manually to the identified participants of the study. The list of academic expatriates provided by the Human Resources Department of each institution consisted of the biographical details such as name, surname, designation, department, country of origin, email address, contact numbers, office location, date employed by the institution, employment status, ID number and staff number. Based on certain biographical information such as office location and number, participants were approached individually through door to door office visits. In total the questionnaire research and data collection procedure yielded 120 responses. Further, in order to increase response rate, the researcher further developed an electronic questionnaire which was distributed to the participants who could not participate during the manual survey. However, only 22 additional responses were received from the electronic survey. In total, a response of 142 participants (52\% response rate) was achieved.

Prior to the administration of the questionnaire whether manually or through online 
survey, participants were informed of their right to withdraw from the study at any time and that participation is voluntary in line with the instructional of ethical precepts. They were also assured of complete anonymity and confidentiality.

The data collected was entered into the computer system, cleaned and checked, coded and then analysed using Statistical Programme for Social Sciences (SPSS) version 21. Various tests were performed to analyse, interpret and make meaning of the data, namely, Descriptive Statistics, ANOVA and the Independent sample T-test. The descriptive statistics were used to make meaning of the raw data which included; frequencies and percentage tables, mean standard deviation, skewness and kurtosis.

\section{RESULTS AND DISCUSSION}

\section{Demographic characteristics of the sample}

The majority of the respondents were male permanent lecturers between the ages of 31-40 years who have worked for University of Durban-Westville for about 2-5 years. Interestingly, they had Doctoral degrees and were on various types of work permits; with 39 per cent of them having obtained permanent residence status and had lived in South Africa for a period of between 5-10 years. The limited number of female expatriates is a point to note.

Table 1: Characteristic of the participants

\begin{tabular}{|c|c|c|c|c|c|}
\hline Characteristic & $\mathbf{N}$ & $\%$ & Characteristic & $\mathbf{N}$ & $\%$ \\
\hline Institutions & & & Type of work permit & & \\
\hline Univ.A & 28 & 20 & General work permit & 22 & 15 \\
\hline Univ.B & 20 & 9 & Critical skills permit & 31 & 22 \\
\hline Univ.C & 13 & 14 & Refugee work permit & 5 & 4 \\
\hline Univ.D & 81 & 57 & Quota permit & 12 & 8 \\
\hline Occupational levels & & & Permanent residence & 56 & 39 \\
\hline Professor & 17 & 12 & Other & 11 & 8 \\
\hline Associate Professor & 11 & 8 & Missing & 5 & 4 \\
\hline Senior Lecturer & 18 & 13 & Age groups & & \\
\hline Lecturer & 86 & 61 & 20-30 years & 13 & 9 \\
\hline Tutor & 9 & 6 & $31-40$ years & 54 & 38 \\
\hline Missing & 1 & 1 & $41-50$ years & 40 & 28 \\
\hline Tenure & & & Above 50 years & 32 & 23 \\
\hline Less than 2 years & 29 & 20 & Missing & 3 & 2 \\
\hline $2-5$ years & 48 & 34 & Participation per faculty & & \\
\hline $5-10$ year & 33 & 23 & Education & 12 & 8 \\
\hline More than 10 years & 27 & 19 & Engineering & 43 & 30 \\
\hline Missing & 5 & 4 & Humanities & 19 & 13 \\
\hline Employment status & & & Management & 15 & 11 \\
\hline Permanent & 84 & 59 & Sciences & 46 & 32 \\
\hline Fixed term contract & 46 & 32 & Missing & 7 & 5 \\
\hline
\end{tabular}




\begin{tabular}{|l|c|c|l|c|c|}
\hline Characteristic & N & $\%$ & Characteristic & N & $\%$ \\
\hline Part-time & 8 & 6 & Reason for choosing SA as host country & & \\
\hline Missing & 4 & 3 & Academic development & 15 & 11 \\
\hline Gender & & & Better opportunities & 3 & 2 \\
\hline Male & 113 & 80 & Close to home & 9 & 6 \\
\hline Female & 25 & 18 & Democracy & 3 & 2 \\
\hline Missing & 4 & 3 & Education system & 40 & 28 \\
\hline Time lived in South Africa & & & Family reasons & 5 & 4 \\
\hline Less than 2 years & 13 & 9 & Good economy & 35 & 25 \\
\hline 2-5 years & 30 & 21 & Research facilities & 25 & 18 \\
\hline 5-10 years & 47 & 33 & Missing & 7 & 5 \\
\hline More than 10 years & 46 & 32 & Reasons for choosing host institution & & \\
\hline Missing & 6 & 4 & Job opportunity & 47 & 33 \\
\hline Qualification & & & Good reputation & 40 & 28 \\
\hline Doctoral degree & 83 & 58 & Head hunted & 6 & 4 \\
\hline Masters degree & 52 & 37 & Personal/family reasons & 3 & 2 \\
\hline Honours degree & 1 & 1 & Contributions & 3 & 2 \\
\hline Bachelors degree & 1 & 1 & Research facilities & 23 & 16 \\
\hline Missing & 5 & 4 & Missing & 7 & 5 \\
\hline
\end{tabular}

The multiple amputation method was applied to deal with the problem of missing values. The area of specialisation/discipline and the department to which the respondents were attached were above 5 per cent threshold of missing value (Gaskin 2014) and were therefore excluded in the reporting. The respondents originate from various countries across the globe, however, the majority; 32 per cent originates from Zimbabwe, 9 per cent from Nigeria and 8 per cent from the Democratic Republic of Congo (See Figure 1).

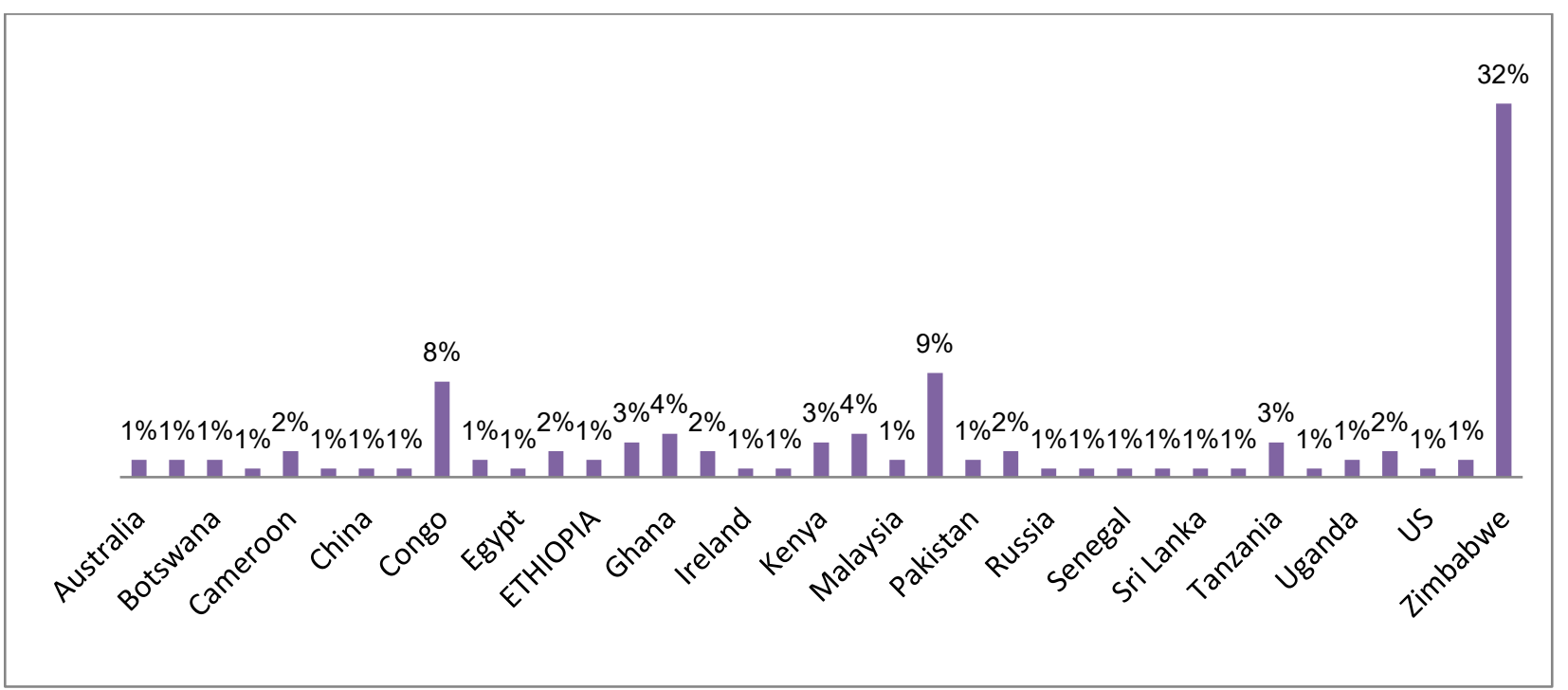

Figure 1: Country of Origin 


\section{DESCRIPTIVE STATISTICS OF MEASURES}

Descriptive statistics of the measures used are presented in Table 2. The Cronbach's alpha coefficients for all measuring instruments but interaction adjustment were acceptable, general adjustment ( $\alpha \geq 0.70, r=0.80)$, overall Work adjustment $(\alpha \geq 0.70, r=0.90)$, General work interaction $(\alpha \geq 0.70, r=0.84)$, and Work activities sub-scale $(\alpha \geq 0.70, r=0.86)$. However, the Interaction adjustment scale attained a coefficient of 0.60 which is also acceptable (Pallant 2013).

Table 2: Descriptive statistics and reliability for the scales

\begin{tabular}{|l|c|c|c|c|c|c|c|c|}
\hline \multicolumn{1}{|c|}{ Variable } & Items & Min & Max & Mean & SD & Skewness & Kurtosis & $\boldsymbol{\alpha}$ \\
\hline $\begin{array}{l}\text { Interaction } \\
\text { adjustment }\end{array}$ & 4 & 4.00 & 20.00 & 13.3224 & 2.83229 & .040 & .251 & 0.60 \\
\hline $\begin{array}{l}\text { General } \\
\text { adjustment }\end{array}$ & 11 & 22.00 & 55.00 & 41.4944 & 8.09131 & -.759 & .294 & 0.80 \\
\hline $\begin{array}{l}\text { Overall Work } \\
\text { adjustment }\end{array}$ & 15 & 25.00 & 70.00 & 49.4560 & 10.17286 & -.681 & .174 & 0.90 \\
\hline $\begin{array}{l}\text { Factor 1 - Gen } \\
\text { work Interaction }\end{array}$ & 8 & 12.00 & 35.00 & 24.1703 & 5.77943 & -.491 & -.644 & 0.84 \\
\hline $\begin{array}{l}\text { Factor 2 - Work } \\
\text { activities }\end{array}$ & 7 & 9.00 & 35.00 & 25.6393 & 5.51033 & -.815 & .075 & 0.86 \\
\hline
\end{tabular}

$\alpha=$ Cronbach alpha coefficient; $S D=$ Standard deviation

Furthermore, the Skewness values reflected in Table 2 reveal that data is almost normally distributed. These values range between 0.40 and 0.815 which is closer to zero. Therefore, one assumes data is from a normal distribution. Similarly, Kurtosis value ranges between .075 and -.644 which is also closer to zero. Kurtosis results reflect less variation of responses in all the factors.

\section{ASSESSING ACADEMIC EXPATRIATES’ GENERAL ADJUSTMENT}

Overall, the respondents demonstrated that they were comfortable with the living conditions and atmosphere. In a way, they have adjusted quite well in as far as living conditions and the atmosphere is concerned. Moreover, about 75 per cent of the respondents were able to tolerate the hygienic standards of host country nationals. This is observed through the responses of a participant who agreed and strongly agreed with the statement "I am able to tolerate the hygienic standards of the host country nationals". Also, about 75 per cent of respondents have adjusted to the shopping in the host country which is reflected in the statement "I have the ability to adjust to the shopping in the host country". Generally, the respondents seemed to have adjusted well in the area of general living standards of the host country. 
Table 3: Percentages of the sample endorsing general adjustment

\begin{tabular}{|c|c|c|c|c|c|}
\hline Item & $\begin{array}{l}\text { Strongly } \\
\text { Disagree } \\
(\%)\end{array}$ & $\begin{array}{l}\text { Disagree } \\
\quad(\%)\end{array}$ & $\begin{array}{l}\text { Neutral } \\
(\%)\end{array}$ & $\begin{array}{l}\text { Agree } \\
(\%)\end{array}$ & $\begin{array}{l}\text { Strongly } \\
\text { Agree } \\
(\%)\end{array}$ \\
\hline \multicolumn{6}{|l|}{ Living conditions and atmosphere } \\
\hline $\begin{array}{l}\text { I am able to eat and enjoy the national food of } \\
\text { the host country }\end{array}$ & 4.93 & 2.82 & 15.49 & 47.89 & 28.87 \\
\hline $\begin{array}{l}\text { I am able to adjust to the transportation system } \\
\text { in the host country }\end{array}$ & 4.23 & 4.93 & 12.68 & 52.82 & 25.35 \\
\hline $\begin{array}{l}\text { I have the ability to adjust to the general living } \\
\text { conditions in the host country }\end{array}$ & 5.63 & 5.63 & 6.34 & 52.82 & 29.58 \\
\hline $\begin{array}{l}\text { I am able to adjust to the climatic and } \\
\text { environmental differences of the host country }\end{array}$ & 2.11 & 11.97 & 7.04 & 43.66 & 35.21 \\
\hline $\begin{array}{l}\text { Back home I maintain a living atmosphere which } \\
\text { is closely comparable to the living the } \\
\text { atmosphere in the host country }\end{array}$ & 1.42 & 7.80 & 20.57 & 44.68 & 25.53 \\
\hline $\begin{array}{l}\text { I am able to adapt to differences in } \\
\text { security in a new cultural environment }\end{array}$ & 1.42 & 9.93 & 12.06 & 52.48 & 24.11 \\
\hline $\begin{array}{l}\text { In my host country I am able to use the } \\
\text { entertainment facilities as the host nationals do }\end{array}$ & 2.84 & 8.51 & 21.28 & 47.52 & 19.86 \\
\hline $\begin{array}{l}\text { I am able to adjust to the quality of education } \\
\text { and schooling system of my children in the host } \\
\text { country }\end{array}$ & 3.57 & 5.00 & 22.14 & 46.43 & 22.86 \\
\hline \multicolumn{6}{|l|}{ General Living Standards } \\
\hline $\begin{array}{l}\text { I am able to tolerate the hygienic standards and } \\
\text { manners of the host country nationals }\end{array}$ & 13.38 & 2.82 & 9.15 & 52.11 & 22.54 \\
\hline $\begin{array}{l}\text { I have the ability to adjust to shopping in } \\
\text { the host country }\end{array}$ & 2.82 & 4.93 & 16.90 & 44.37 & 30.99 \\
\hline
\end{tabular}

\section{ASSESSING ACADEMIC EXPATRIATES' INTERACTION ADJUSTMENT}

The majority of the respondents, about 53 per cent felt that they were unable to proficiently use the local language. This is reflected in the 25.35 per cent of the respondents who indicated that they strongly disagree and 27.46 per cent of respondents who indicated that they disagree with the statement "I am able to demonstrate proficient use of local language". However, 21.8 per cent of the respondents were neutral about their language proficiency. This may indicate some level of being unsure or lack of confidence in their language proficiency. Only about a quarter, 25 per cent of respondents were confident about their language proficiency. This can be observed through the 16.20 per cent of respondents who agreed and 9.15 of respondents who strongly agreed with the statement.

Table 4: Percentages of the sample endorsing Interaction adjustment items

\begin{tabular}{|l|c|c|c|c|c|}
\hline \multicolumn{1}{|c|}{ Item } & $\begin{array}{c}\text { Strongly } \\
\text { Disagree (\%) }\end{array}$ & $\begin{array}{c}\text { Disagree } \\
\text { (\%) }\end{array}$ & $\begin{array}{c}\text { Neutral } \\
\text { (\%) }\end{array}$ & $\begin{array}{c}\text { Agree } \\
\text { (\%) }\end{array}$ & $\begin{array}{c}\text { Strongly } \\
\text { Agree (\%) }\end{array}$ \\
\hline $\begin{array}{l}\text { I am able to demonstrate the proficient use } \\
\text { of the local language }\end{array}$ & 25.35 & 27.46 & 21.83 & 16.20 & 9.15 \\
\hline $\begin{array}{l}\text { I am able to correctly interpret and utilise } \\
\text { nonverbal cues (i.e. body language) specific } \\
\text { to the host culture }\end{array}$ & 5.63 & 17.61 & 30.28 & 33.80 & 12.68 \\
\hline $\begin{array}{l}\text { I am able to adapt easily to developing and } \\
\text { maintaining new social relationships }\end{array}$ & 6.38 & 2.84 & 19.15 & 56.03 & 15.60 \\
\hline $\begin{array}{l}\text { I have the ability to demonstrate } \\
\text { interpersonal skills appropriate to the host } \\
\text { culture }\end{array}$ & 1.42 & 3.55 & 17.02 & 57.45 & 20.57 \\
\hline
\end{tabular}


About 46.5 per cent of respondents were positive that they can correctly interpret and utilise nonverbal cues such as body language. This is reflected in 33.80 per cent of the respondents who agreed and 12.68 per cent of the respondents who strongly agreed with the statement "I am able to correctly interpret and utilise nonverbal cues (i.e. body language) specific to the host culture". But 30.28 per cent of the respondents were neutral about their ability to interpret and utilise nonverbal cues. In this way, these respondents are not certain or they lack confidence in this particular area of communication.

Interaction adjustment relates to socialising and integrating with the host country nationals (Black 1988; Black et al. 1991). According to Howe-Walsh and Schyns (2010) it entails feeling at ease to interact and cooperate with locals. One of the key ways of interacting with others is by means of communication. Therefore, interaction adjustment could be easier if expatriates have the confidence to interact with locals through communication in mutually intelligible ways.

However, the majority of respondents (53\%) felt they were unable to demonstrate proficient use of the local language. Language symbolise that individuals have their own unique way of communicating (Yusuf and Zain 2014). Language barriers may lead to various communication problems including communication breakdown and ineffective communication. Consequently, one may envisage minimal interaction levels as a result of avoiding miscommunication and mis-conceptualisation of messages between a sender and a receiver. Some scholars such as Nkuna (2010) have reiterated that language has the ability to connect people and build strong relationships. Therefore, lack of communication as revealed in this study may result in the disconnection between academic expatriates and host nationals. As reported by Froese (2012) academic expatriates in Korea felt that communication difficulties limited their day to day activities.

Moreover, Yusuf and Zain (2014) are of the opinion that communication may not be confined to verbal means but it incorporates gestures, postures, silence, emotional expressions, touch, physical appearance and other non-verbal cues. For this reason, the issues of language and communication become complex to an extent that one has to go beyond mere verbatim expression but to also understand the meaning of certain facial expressions and gestures attached to certain traditions, practices and culture. This is because one tends to observe and rely on non-verbal cues if he or she finds difficulty in comprehending verbal communication (Yusuf and Zain 2014). Therefore, knowledge of local language and non-verbal cues attached to it is very critical to enable academic expatriates in the KZN province to interact and integrate with the locals in a way that can enhance their settlement. 


\section{ASSESSING THE ACADEMIC EXPATRIATES' WORK ADJUSTMENT}

The majority of respondents felt that they were able to adjust to various work-related areas such as working hours, working with co-workers and interacting with staff and students at various levels. In addition, respondents felt that they were able to demonstrate sensitivity to the local culture and they were confident that they understood the business culture. However, 59 per cent of respondents indicated that they were unhappy with the coordination of work permit application as they disagreed and strongly disagreed with the statement "I am happy with the coordination of the work permit application process within the university". Therefore, in the main, the majority of respondents have adjusted well in general work interaction with the exception to the discomfort caused by the work permit application process.

Table 5: Percentages of the sample endorsing work adjustment

\begin{tabular}{|c|c|c|c|c|c|}
\hline Item & $\begin{array}{l}\text { Strongly } \\
\text { Disagree } \\
(\%) \\
\end{array}$ & $\begin{array}{c}\text { Disagree } \\
(\%)\end{array}$ & $\begin{array}{c}\text { Neutral } \\
(\%)\end{array}$ & $\begin{array}{c}\text { Agree } \\
(\%)\end{array}$ & $\begin{array}{l}\text { Strongly } \\
\text { Agree (\%) }\end{array}$ \\
\hline \multicolumn{6}{|l|}{ General Work Interaction } \\
\hline $\begin{array}{l}\text { I am able to adapt to the time required for } \\
\text { working at this university }\end{array}$ & 11.97 & 7.04 & 7.75 & 45.07 & 28.17 \\
\hline $\begin{array}{l}\text { I am able to adjust to working with host } \\
\text { country co-workers }\end{array}$ & 2.11 & 2.82 & 12.68 & 50.70 & 31.69 \\
\hline $\begin{array}{l}\text { I am able to make use of management and } \\
\text { leadership techniques to accommodate the } \\
\text { needs and expectations of employees and } \\
\text { business associates in the host culture }\end{array}$ & 3.52 & 8.45 & 13.38 & 50.70 & 23.94 \\
\hline $\begin{array}{l}\text { I feel that I am welcomed and accepted by } \\
\text { host nationals/colleagues and we have good } \\
\text { working relationship }\end{array}$ & 7.04 & 4.23 & 23.24 & 43.66 & 21.83 \\
\hline $\begin{array}{l}\text { I am able to demonstrate sensitivity to local } \\
\text { customs and norms when teaching new skills } \\
\text { or providing students with information }\end{array}$ & 6.38 & 6.38 & 15.60 & 57.45 & 14.18 \\
\hline I am able to understand the university culture & 12.77 & 6.38 & 17.73 & 44.68 & 18.44 \\
\hline $\begin{array}{l}\text { I have worked / attended conferences / } \\
\text { visited / studied / lived in South Africa before } \\
\text { my employment at this university }\end{array}$ & 9.22 & 4.26 & 12.77 & 41.84 & 31.91 \\
\hline $\begin{array}{l}\text { I am happy with the coordination of the work } \\
\text { permit application process within the } \\
\text { university }\end{array}$ & 51.43 & 7.86 & 12.14 & 17.14 & 11.43 \\
\hline \multicolumn{6}{|l|}{ Work Activities } \\
\hline $\begin{array}{l}\text { I am able to understand the university } \\
\text { policies and procedures }\end{array}$ & $3.52 \%$ & 2.82 & 16.90 & 45.77 & 30.99 \\
\hline $\begin{array}{l}\text { I am able to interact with students and staff at } \\
\text { all levels }\end{array}$ & $2.84 \%$ & 7.80 & 13.48 & 39.01 & 36.88 \\
\hline $\begin{array}{l}\text { I get adequate support from the university to } \\
\text { enable me to adjust at work }\end{array}$ & $9.15 \%$ & 5.63 & 22.54 & 42.25 & 20.42 \\
\hline $\begin{array}{l}\text { I am able to adjust to my current work-related } \\
\text { tasks and responsibilities }\end{array}$ & $5.63 \%$ & 7.04 & 10.56 & 44.37 & 32.39 \\
\hline I am comfortable working in this university & $2.82 \%$ & 2.82 & 21.13 & 47.89 & 25.35 \\
\hline $\begin{array}{l}\text { I feel that I stand a good chance of promotion } \\
\text { in the near future }\end{array}$ & $14.08 \%$ & 7.04 & 28.87 & 39.44 & 10.56 \\
\hline $\begin{array}{l}\text { My expectations are fully met and I feel } \\
\text { fulfilled working at this university }\end{array}$ & $10.71 \%$ & 13.57 & 34.29 & 27.86 & 13.57 \\
\hline
\end{tabular}


Generally, the respondents have adjusted well in the area of work activities as they indicated that they understood university policies and procedures, they get adequate support from their respective universities and they felt a sense of fulfilment.

\section{DEMOGRAPHIC GROUP DIFFERENCES PERTAINING TO GENERAL INTERACTION, GENERAL ADJUSTMENT AND WORK ADJUSTMENT}

The One-Way ANOVA test showing differences between various constructs and demographic characteristics are presented in Table 6. Where necessary, Post Hoc test was performed to establish where the significant mean differences were observed. The results revealed that a significant General Adjustment means differences between foreign nationals at Univ. A and Univ. $\mathrm{D}$ as well as Univ. $\mathrm{B}, F=3.227, p=0.025$. The post-hoc test showed that Univ. A differs significantly with those at Univ. D and those at Univ. B. The effect size is 0.8 which is medium according to Cohen (1988).

Based on the number of years lived in South Africa, significant mean differences were found in General Adjustment and Work adjustment. For General Adjustment, those who have stayed in South Africa for 2-5years differ significantly with those who have been in South Africa for more than 6 years, $(F=3.809, p=0.012)$ as well as with those who have lived in South African for more than 10 years. The effect size which is medium is 0.8 according to Cohen (1988). For Work Adjustment, those who have lived in South Africa for 2-5years only differs significantly with those who have lived in South Africa for 6-10 years, $F=3.205, p=$ 0.025. Age, tenure, occupational level and nature of employment did not have any significant effect on the various types of adjustment levels of expatriate academics.

General adjustment entails adjustment to the general living conditions and non-work factors in the new country (Black 1988; Black et al. 1991). Also, according to Howe-Walsh and Schyns (2010) general adjustment has to do with establishing social relations/networks, being able to find accommodation and not feeling isolated (not feeling alien). As revealed in the study mean differences in general adjustment of academic expatriates based at Univ. A and Univ. D, as well as those of Univ. A and Univ. B. Perhaps, the location, size and a number of academic expatriates employed by the Univ. D suggest more exposure and sensitivity towards diversity as compared to other two universities.

Table 6: ANOVA of General Interaction, General Adjustment and Work Adjustment based demographic characteristics

\begin{tabular}{|l|c|c|c|c|c|c|}
\hline \multicolumn{1}{|c|}{ Variable } & Univ. A & Univ. D & Univ. C & Univ. B & $\boldsymbol{F}$ & P \\
\hline Interaction Adjustment & 12.70 & 13.39 & 15.08 & 13.75 & 1.885 & 0.135 \\
\hline General Adjustment & 37.40 & 43.06 & 43.30 & 43.21 & 3.227 & $0.025^{\star}($ effect size=0.8) \\
\hline
\end{tabular}




\begin{tabular}{|c|c|c|c|c|c|c|}
\hline Variable & Univ. A & Univ. D & Univ. C & Univ. B & $\boldsymbol{F}$ & $\mathbf{P}$ \\
\hline Work Adjustment & 47.65 & 49.72 & 53.00 & 54.07 & 2.245 & 0.086 \\
\hline & $<2$ years & $2-5$ & $6-10$ & $10+$ & & \\
\hline Interaction Adjustment & 14.61 & 13.39 & 13.33 & 13.58 & 0.685 & 0.562 \\
\hline General Adjustment & 42.07 & 38.20 & 42.96 & 44.18 & 3.809 & $0.012^{*}$ (effect size $\left.=0.8\right)$ \\
\hline Work Adjustment & 53.62 & 45.97 & 52.42 & 5051 & 3.205 & $0.025^{*}$ \\
\hline
\end{tabular}

${ }^{*} \mathrm{p} \leq 0.05 ;{ }^{* *} p \leq 0.01 ;{ }^{* \star *} \mathrm{p} \leq 0.001$

In contrast, significant mean differences were observed in the general adjustment of academic expatriates who have lived in South Africa for a period of between 2-5 years and those who have lived in South Africa for a period of above 10 years. These findings are in line with the U-Curve cross-cultural adjustment model. According to this model, adjustment is a process comprising of four cross-cultural adjustment stages, namely; 1) honeymoon/euphoria, 2) cultural shock, 3) adjustment and 4) mastery (Lysgaard 1955). Therefore, upon arrival in South Africa (less than 2 years) academic expatriates experience the honeymoon stage. During this period, they feel excited about the new encounters in the host country/new environment. Succeeding this period, cultural shock confronts them as they face the realities of the host country's cultural practices. Culture shock is defined as a primary set of emotional reactions to the loss of perceptual reinforcements from one's own culture to new cultural stimuli which have little or no meaning. Culture shock is uncertainty that leads to anxiety, depression and isolation in the event people are faced with an unfamiliar culture (Rajasekar and Renand 2013). Scholars such as Du Plessis (2009) concur that negative feelings about the host country and its people and a longing to return home are some of the symptoms caused by culture shock. Therefore, as revealed in this study, these are some possible difficulties that academic expatriates in the KZN region may be experiencing.

Intercultural competence lead to appropriate behaviours with a foreign culture (Graf and Mertesacker 2009), and as such, academic expatriates should have basic knowledge of the foreign culture, intercultural sensitivity and effective intercultural behaviour. However, OsmanGani and Rockstuhl (2009) argue that different job assignments require various degrees of contact with the local culture which may be very different from or similar to the home culture. In the case of academic expatriates based in the higher learning institutions under study, they deal with local communities at various levels where the understanding and appropriate use of local culture becomes imperative. Therefore, as revealed in this study, academic expatriates who have been in South African for about 2-5 years are going through different stages of this adjustment process while those who have been in South Africa for 10 years and more have reached the mastery stage and have fully adjusted. But those who have been in South Africa for a period of between 2-5 years still experience different adjustment challenges. 
However, one may not ignore the argument relating to the individuals' differences (Black and Mendenhall 1991). These scholars are of the opinion that individuals' differences may lead to differences in the amplitude of different adjustment stages and would also cause these stages to occur at different intervals. Therefore, academic expatriates may experience the adjustment differently. Consequently, different adjustment shape may be formed other than a U-shape. In the same vein, Takeuchi and Chen (2013) contest that prior international experience contributes towards one's adjustment. Hence, academic expatriates who have prior international experience may experience adjustment differently due to their exposure to different cultural practices.

\section{LIMITATIONS}

One of the key limits of this study is that the findings of this study can only be generalized within the confines of the KZN region. To use the observations and conclusions of this study as meaningful for the rest of South African institutions of higher learning is possible but not reliable enough. However, the usefulness of these findings to other institutions of higher learning in South Africa as well as other institutions of similar nature should not be underestimated as the South African national setting is a real host setting for international labour and human resources, with varied but also constant characteristics. Moreover, due to the specific focus in the higher education sector, the findings may be irrelevant to other sectors considering the nature, dynamics and practices of the higher education sector. Some characteristics and factors, however, may be general and true of other sectors too beyond the higher education sector.

\section{FUTURE RESEARCH}

In future, studies of this nature and focus may involve the participation of local communities as they interact with academic expatriates through community engagement and community based research projects. Some of the academic expatriates reside or conduct business in the very communities. Therefore, it would be interesting to establish the perspective of local communities in terms of their views and experience of interacting with academic expatriates. Also, students' insight would be valuable in relation to their interaction and relations with foreign lecturers. The way expatriate individuals work and network in South Africa, keeping to themselves or mixing and mingling to integrate into South African society and industry, may also be of interest to future studies.

\section{CONCLUSION AND RECOMMENDATIONS}

This study has noted that cross-cultural adjustment for expatriate academics is crucial in the life 
of the academics and South Africa as a host country, and the universities as hosting academic institutions. Academic expatriates, the study observed, are important for the wealth of skills that they bring which fill the gap created by shortages of human resources some of which are owing to the legacy of apartheid in South Africa. The country and respective universities should develop policies and regulations that will permit effective training and development initiatives to sufficiently familiarise and induct expatriate academics into their host environments. The expatriates should be enabled and also make their own enabling efforts to develop critical adjustment skills that will allow them to navigate and negotiate their new life and work environment.

Such skills may include, but are not limited to; communication and basic language skills and cultural sensitivity skills. These initiatives could well be integrated within the skills and professional development programmes that usually reside in the Training and Development Unit or Academic Development Unit and in some instances in the Language Services Unit. Howe-Walsh and Schyns (2010) concur that training should be offered to address cross-cultural intelligence and ensure proper integration of internal staff in the host institution. This study notes that such skills as Critical Diversity Literacy suggested by Steyn (2015) as a sociological way of cultivating and managing social cohesion amongst diverse people should be facilitated and administered in the South African higher education setting.

The study notes that international skills have over the years proved to be a great source of academic talent and professionalism in South Africa. Therefore, institutions that engage this international labour should assist the adjustment process of academic expatriates through providing necessary support and cultivating a conducive work environment that promotes superior work performance. But the support offered should further be extended to a level where government legislations, processes and procedures are influenced to enable quick processing of work permits and other immigration processes and procedures. This influence is well within the space of academic research and innovation and good policy making. Therefore, scientific knowledge should be produced that will influence the current work permit application process and further deepen the professionalism in immigration and Home Affairs procedures. Making the higher education sector in South Africa adaptable and adjustable sector would, in the view of this study, be good for economic development, national and international relations.

In conclusion, the internationalisation of the higher education landscape in South Africa has led to diversity and expatriation issues. Therefore, this study shed some light on critical diversity management issues that call for institutional intervention strategies. Through this study, awareness of adjustment challenges of academic expatriates was raised for higher learning institutions and host country nationals to take cognisance of and offer appropriate 
support. Also, through this study a call is made for transformed and accommodative human resources practices that respond to the global changes, especially practices that address the needs of academic expatriates. The higher education landscape in South African needs to be critically diverse and be compliant to social and cultural cohesion. If decolonising higher education and its transformation make the university a freer and more human space, the crosscultural adjustment of expatriates should be a priority.

\section{REFERENCES}

Black, J. S. 1988. Work-role transitions: A study of American expatriate managers in Japan. Journal of International Business Studies 19: 277-294.

Black, J. S., M. Mendenhall and G. R. Oddou. 1991. Towards a comprehensive model of international adjustment: An integration of multiple theoretical perspectives. Academy of Management Review 16(2): 291-317.

Black, J. S. and M. Mendenhall. 1991. The U-curve adjustment hypothesis revisited: A review and theoretical framework. Journal of International Business Studies 22(2): 225-247.

Cohen, J. 1988. Statistical power analysis for the behavioural sciences. $2^{\text {nd }}$ Edition. Hillsdale, NJ: Erlbaum.

Du Plessis, A. J. 2009. An overview of influence of globalization and international on domestic human resource management in New Zealand. International Review of Business Research Papers 5(2): $1-18$.

Fanon, F. 1967. Black skin, white masks. New York: Grove.

Fomunyam, B. N. 2012. Caught between two worlds: The (re)negotiation of identity among Cameroonian migrants in Durban. Alternations 19(1): 199-216.

Froese. F. J. 2012. Motivation and adjustment of self-initiated expatriates: The case of expatriate academics in South Korea. The International Journal of Human Resource Management 23(6): $1095-1112$.

Gaskin, J. 2014. Statistics basics, data screening and missing values (SEM Boot Camp). https://www.youtube.com/watch?v=C_Jf410PF18

Graf, A. and M. Mertesacker. 2009. Intercultural training: Six measures assessing training needs. Journal of European Industrial Training 33(6): 539-558.

Howe-Walsh, L. and B. Schyns. 2010. Self-initiated expatriation: Implications for HRM. The International Journal of Human Resource Management 21(2): 260-273.

Huff, K. C. 2013. Language, cultural intelligence and expatriate success. Management Research Review 36(6): 596-612.

Lysgaard, S. 1955. Adjustment in a foreign society: Norwegian Fulbright grantees visiting the United States. International Social Science Bulletin 7: 45-51.

Maharaj, A. 2011. The impact of globalisation on South African higher education institutions, patterns of academic inflow into the South African higher education system. Delhi Business Review 12(1): $37-50$.

Nkuna, P. H. 2010. Preparing for talent: Towards transformed indigenous African language disciplines at South African universities. South African Journal of African Languages 30(2): 222-233.

Nyamnjoh, F. B. 2006. Insiders and outsiders: Citizenship and xenophobia in contemporary Southern Africa. Zed Books, New York.

Ojong, V. B. 2012. Pragmatic and symbolic negotiation of home for African migrants in South Africa. Alternations 19(1): 262-279. 
Okpara, J. O. 2010. Personal characteristics as predictors of expatriate managers' cross-cultural adjustment in Nigeria. African Journal of Business and Economic Research 5(1): 113-133.

Osman-Gani, A. M. and T. Rockstuhl. 2009. Cross-cultural training, expatriate self-efficacy, and adjustments to overseas assignments: An empirical investigation of managers in Asia. International Journal of Intercultural Relations 33: 277-290.

Pallant, J. 2013. SPSS Survival Manual: A step by step guide to data analysis using SPSS. $5^{\text {th }}$ Edition. London: Open University Press.

Rajasekar, J. and F. Renand. 2013. Culture shock in a global world: Factors affecting culture shock experienced by expatriates in Oman and Oman expatriates abroad. International Journal of Business and Management 8(13): 1833-8119.

Ren, H., M. A. Shaffer, D. A. Harrison, C. Fu and K. M. Fodchuck. 2014. Reactive adjustment or proactive embedding? Multi study, multi-wave evidence for dual pathways to expatriate retention. Personnel Psychology 67: 203-239.

Selmer, J. and J. Lauring. 2013. Cognitive and affective reasons to expatriate and work adjustment of expatriate academics. International Journal of Cross Cultural Management 13(2): 175-191.

Steyn, M. 2015. Critical diversity literacy: Essentials for the twenty-first century. In Routledge International Handbook of Diversity Studies, ed. Vertovec. New York: Routledge.

Takeuchi, R. and J. Chen. 2013. The impact of international experience for expatriates' cross-cultural adjustment: A theoretical review and a critique. Organisational Psychology Review 3(3): 248290.

Vrosmans, P. and M. van Engen. 2013. Presumed cultural similarity paradox, expatriate adjustment and performance across the border or over the globe. Journal of Global Mobility 1(2): 219-238.

Wocke, A. and S. Klein. 2002. The implications of South Africa's skills migration policy for country competitiveness. Development Southern Africa 19: 441-454.

Yusuf, B. N. and A. B. Zain. 2014. The effect of cultural diversification on working performance of expatriates in the higher learning institutions. Advances in Environmental Biology 8(11): 978986.

Žižek, S. 2017. Against the double blackmail: Refugees, terror and other troubles with the neighbors. London, Allen Lane. 